\title{
Western discourses on the Chinese presence in Africa
}

\author{
By Ross Anthony \\ Research Fellow, Centre for Chinese Studies, Stellenbosch University
}

Elevator conversations can tell us a lot about public discourses. I recently struck up a conversation with a man in an elevator. When I told the man that my job entailed researching the Chinese presence in Africa, he responded with the comment: "We'd better keep an eye on them, soon they will be taking over the entire continent". His response did not shock me if only because it was the most recent of a litany of likeminded comments I had heard since my return to South Africa a few months ago. Similarly, in my preced-ing years spent in the United Kingdom, protests of "neocolonialism", "exploitation" and "propping up tyrants" arose almost as knee-jerk reactions to the topic of China-Africa relations.

In a very blunt sense, such comments reflect an irrefutable increase in Chinese economic interests within Africa. However, what such opinions conceal is far more interesting. The vast majority of people who frown upon Chinese economic interests in Africa do so without a whiff of reflexive knowledge regarding their own countries' often lengthy involvement in precisely the same process and in precisely the same place. This alarmist reaction to Chinese investment in the Africa must, almost by necessity, co-exist with its diametric opposite: the assumption that western involvement on the continent is nurturing, benign and committed. This has been given a popular boost in recent years with the rise of the Euro-American phenomenon of charity-as-media spectacle, in which rock and film stars engage in high profile acts of giving and advocacy to their chosen African region.

If anything, this points to an ideological blind spot present within the western world. Certain historians have argued that rise of western capitalism and the accumulation of wealth in Europe's metropoles was inextricably bound to resource extraction in the colonies. Moreover, following decolonization, former colonial powers have continued to use their privileged positions in order to secure lucrative deals in extracting mineral and energy wealth. Such involvement heavily overshadows the Chinese presence. For instance, in 2009, China's special envoy for African affairs pointed out that China received 8.7 percent of Africa's oil exports while the European Union and America each received 33 percent.

Public ignorance at the west's extractive reach into places such as Africa can be at least partially attributed to the fact that, within advanced, technological societies, products consumed on a daily basis have a magical quality about them: one rarely thinks about the origins of the petrol in your car, or the packaging enclosing your microwave meal. While trends in sustainable consumption are changing the way people think about this, for the most part, the politics and economics of resource extraction which sustains such a lifestyle remains concealed from everyday life. Thus, one can at once engage in charitable acts of giving to the developing world while potentially perpetuating economic disparity simply by living an ordinary western lifestyle. 
This leads to a more brutish, realpolitik reason as to why so much negative commentary against China's "colonization" of Africa exists within contextual vacuum. It has been estimated that it would require several planets, each the size of earth, to sustain a global population in which each individual consumes what the average American consumes. As China's vast population shifts into middle-income status, as its citizens build more houses and buy more cars - in short, as it becomes more like the western countries - it increasingly threatens the long-privileged access to increasingly scarce resources which the west has enjoyed for centuries. At the same time, the west has long promised the developing world that through liberalized economic policies, it too could become like them. The adage of "be careful what you wish for" seems pertinent here.

These are some of the reasons which may help explain the current outrage at China's "encroachment" into Africa. One possible way of addressing the problem is to encourage, amongst media, policy makers and think tanks, more nuanced accounts of the Chinese presence in Africa. In doing so, it would become increasingly apparent within the popular western imagination that the Chinese, like their western counterparts, engage in a number of varying commercial and political strategies in a number of different African countries. This may lead to the realization that more, rather than less, interest from global players in the continent is actually a good thing. For instance, following the European financial crises, African countries had alternative markets for their products. The more trading partners Africa has to choose from, the more agency is granted to African states, the more competitive the west has to become to maintain its privileged position. Greater choice, increased commercial autonomy for African states, more competitive global markets - now those are things that many citizens in the western world, my acquaintance in the elevator included, would be more than happy to subscribe to. 